\title{
Research on the Generation Mechanism and Countermeasures of Marxism Belief of Chinese College Students in the New Era
}

\author{
Yanjuan Qi \\ College of Humanities and Social Sciences, Heilongjiang Bayi Agricultural University, Daqing, China \\ Email: 25354716@qq.com
}

How to cite this paper: Qi, Y. J. (2018). Research on the Generation Mechanism and Countermeasures of Marxism Belief of Chinese College Students in the New Era. Open Journal of Philosophy, 8, 522-529. https://doi.org/10.4236/ojpp.2018.85036

Received: July 4, 2018

Accepted: November 12, 2018

Published: November 15, 2018

Copyright $\odot 2018$ by author and Scientific Research Publishing Inc. This work is licensed under the Creative Commons Attribution International License (CC BY 4.0).

http://creativecommons.org/licenses/by/4.0/

\begin{abstract}
The belief of college students is of great practical significance to the development of the country, the prosperity of the nation, the progress of society and the existence of the individual. On the basis of clarifying belief and Marxism belief, this paper emphatically analyzes the generation mechanism of belief from three aspects, namely, the needs of the subjects, the choice of the subjects and the practice of the subjects, and puts forward the countermeasures for the four dimensions on how to carry out the Marxism belief education in colleges and universities.
\end{abstract}

\section{Keywords}

College Students, Marxism Belief, Generation, Countermeasures

\section{Introduction}

The report of the 19th National Congress of the Communist Party of China clearly points out that socialism with Chinese characteristics has entered a new era, and the whole society is striving for the great rejuvenation of the Chinese nation. It is of great significance to emphasize the Marxism belief education for Chinese college students in the new century.

\section{The Belief and the Connotation of Marxism Belief}

\subsection{Connotation of Belief}

Scholars have many researches on beliefs, which generally refers to the extreme belief and conviction of someone, some kind of claim, creed, religion, etc., and act as examples or guides. It contains the belief subject, the belief object and the 
belief mediator. The subject of faith refers to the carrier of the choice of faith, that is, the believer, including the individual and the community (Zhang \& Liu, 2014). The object of belief, that is, the specific object of belief, can be human, organization, abstract symbols, gods, religions, or the value of a system of beliefs, doctrines, and theories formed by words. The belief mediator is understood as the conscious pursuit of the subject of the belief, and it is a process and relationship between the subject and the object (Zhang \& Deng, 2015).

\subsection{Morphology of Belief}

The morphology of belief can be divided from different angles. Based on people's daily experience and observation, belief can be divided into five basic forms: religious belief, political belief, moral belief, personal life belief and social ideal belief. Among them, religious belief is the oldest, most mature and most influential form of human belief. Political belief is a subjective state of mind that is believed to be a political theory and a belief in people's political life, which contains the unity of the individual and the social level. Moral belief emphasizes the belief factors or levels in the formation of morality, and emphasizes the moral objects or contents in the formation of belief (Huang, 2015). The two elements merge into one element as a kind of internal integration and form the moral belief. Personal life belief refers to the holding and holding of an individual's transcendence in the meaning and value of his life, the future and fate of his life, and the state and destination of his life. Social ideal belief refers to the certain class or the nation, whose grasp and holding on the ideal to the specific social historical development stage and the ultimate development goal.

\subsection{Marxism Belief}

\subsubsection{Connotation}

The academic world gives different definitions, and Liu Jianjun points out that the Marxism belief is a conviction and faith in Marx's doctrine and used as a guide to action. Huang Mingli, from the world view, values, and social systems three aspects to explain, he points out that Marxism belief is to believe in and fulfill the basic ideas and methods of dialectical materialism and historical materialism, it shows respect and awe to those people creating the history, it is the political belief of the ideal society of communism (Liu, 2016). Some scholars also analyze from the perspective of ideology and social ideal. They all agree that Marxism belief is closely related to communism, but different from religious belief, it is a new kind of belief in human development.

In conclusion, Marxism belief is the conviction of the belief subject to the ultimate direction of Marxism theory, that is, the "conviction" of Communist society. It is sure that everyone in the Communist society will achieve "free and comprehensive development" and act as a guide for action.

\subsubsection{Characteristics}

First, the Marxism belief is the dialectical unity of the scientific truth and the ra- 
tionality of value (Qin, 2013). This is the objective reflection of Marxism inner nature. With the guidance of scientific truth, the proletariat can finally accomplish the great value goal of transforming human society and realizing the free and all-round development of communism and human beings.

Second, the Marxism belief is the dialectical unity of idealism and reality (Liu, 2013). The Communism pursued by Marxism is based on social practice and is the inevitable trend of social development. It embodies the ultimate goals and milestones, the organic combination of ideal and the realization of ideal social conditions.

Third, the Marxism belief is the dialectical unity of the ultimate concern of the whole society and the ultimate concern of the individual. Communism has the irresistible charm of belief, it comes from one hand to correctly grasp the objective law of social development, on the other hand, it regards each individual's free and comprehensive development as the ultimate goal of social development. It also embodies the unity of social value orientation and personal value orientation.

\section{The Generation Mechanism of the Marxism Belief of College Students}

The generation of the belief is the process of the needs of belief subject, the choice of belief subject and the practice of belief subject. It can be generally understood that because the subject of belief has an inner spiritual need, it will conduct a belief exploration, find a belief in the belief exploration that is united with its own value and pursuit, will make a choice, and then put it into practice, and then regulate itself (Chen \& Wei, 2016). Behavior, ultimately, internalizes the belief in the heart, externalizes the line, and strengthens the belief. Including the motive force of belief, key points and the process of generating three key elements and three elements. The graph is shown as Figure 1.

\subsection{The Motive Force of Belief Generation-Satisfy the Need of Belief Subject}

Marx and Engels point out that "every characteristic of human nature, every kind of life instinct, will become one of human needs." Need is the starting point and motive force of individual behavior, and belief is the inner spiritual need of human beings. Marxism can meet and satisfy the needs of the belief subject, because it answers people's thinking about the meaning of life, the value of life,

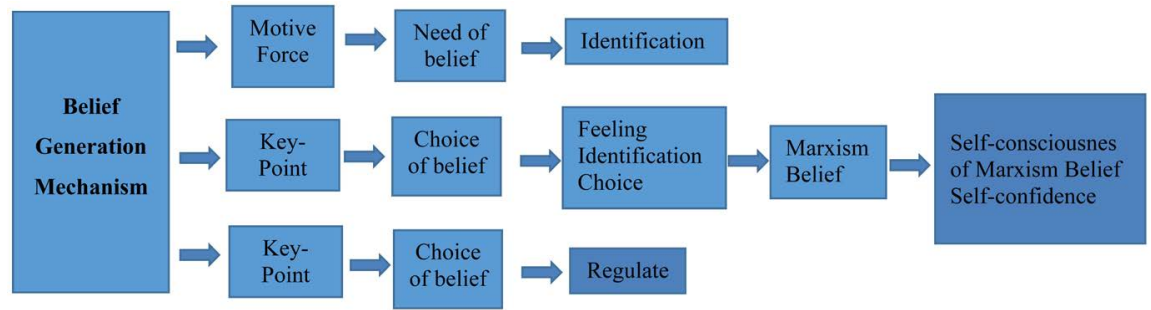

Figure 1. Belief generation mechanism. 
self-realization and the pursuit of happiness. Marxism points out that putting the individual's limited life into human's liberation, and promoting the full and free development of human beings, then individuals can surpass themselves, obtain the immortality of life, and realize the value of life. In the process of close combination and common struggle between individuals and society, individuals can gain a sense of security, belonging and a sense of happiness and care $(\mathrm{Hu}$, 2013). In the Communist society, people can realize the dream of free and comprehensive development. Marxism of science has broken the religious description of the nihilistic world with its scientific nature, truth and practice, and gained the acceptance and identification of the belief subject. This is a leap from Marx's “true knowledge" to "true faith".

\subsection{The Key Point of Belief Generation-Accomplish the Choice of Belief Subject}

The belief subject is a process of accomplishing the choice of belief, which is embodied in emotion and will, on the basis of this to make the choice of belief in Marxism, eventually form the Marxist theory of self-conscious, self-confidence and firm the belief in Marxism.

Belief in emotion. From the psychological point of view, emotion is a kind of subjective attitude experience, which is the motivation of stimulating people's mental activities and behavioral activities. The emotion of the belief subject is a lasting and intrinsic motive for people to pursue their belief. The emotional resonance of the belief subject comes from Marx's love for human life and human beings. It comes from Marx's self-confidence, optimism and emotion, strong sense of social responsibility and mission. Marxism belief contains deep concern for the destiny of mankind and great sympathy for the working people. They are the core emotional elements of Marxism belief. It's a great interpretation of the greatness of Marxism in the ultimate sense of social responsibility for the liberation of all mankind.

Belief in will. The will is the psychological state of the belief subject's own motivation and purpose to be put into practice with conscious effort, which is a indispensable part and has the characteristics of tenacity, causality, decisiveness and self-discipline. The firm will of belief subject can internalize the belief in the concept, and can control its own behavior and direction at any time, and can eliminate all kinds of interference factors and hold on belief to the last. On the basis of belief need satisfaction, theoretical identification and emotional resonance, the Marxist belief will is the key to choose and generate Marxism belief.

Belief in choice. The belief subject's choice in belief is restricted by the objective environment of society and historical conditions. Nowadays, the objective historical conditions such as economic globalization, political democratization and cultural pluralism provide possibility for belief selection. At the same time, in the range of objective conditions, the freedom of the subject's choice is embodied in the fact that the subject decides his belief by his own consciousness, awareness, knowledge, experience and even conscience, to some extent, the be- 
lief subject has the freedom to choose belief. But people are often in the dilemma and contradiction of the choice of belief, such as choosing religious belief or communism belief? Personal life belief or social ideal belief? In general, individuals will choose belief according to their preference and value analysis. Once the choice of belief is made, the corresponding responsibility is required. Choosing Marxism as belief, means we should be responsible for promoting social development and progress and regard the realization of communism as the goal of life (Luo, 2016).

Self-consciousness and self-confidence. The meaning of Self-consciousness used to indicate self-knowledge, but also some scholars think self-consciousness means that people understand the significance of their own activities to a certain extent in social activities, and have a clear purpose and plan. Self-confidence is the confidence and faith in one's abilities and opinions. In this paper, it illustrates that self-consciousness and self-confidence come from the belief subject after belief choice, refers to the consciousness and confidence of Marxism theory, this is because the Marxism, as a human emancipation theory, itself has strong practicality, and can transform its own theory and value into reality, and realize the unity of ideal and reality. The self-consciousness and self-confidence of belief subject can be understood as due to the subject has deeply perceived that the object has a strong respect for the ultimate value of the subject, the highest judgment standard and the constant pursuit of behavior.

\subsection{Generation of Belief}

Romain Rolland says that belief is not a kind of knowledge, but a kind of behavior, it only makes sense when being practiced. The ultimate sign of a belief is to put the belief in the highest value pursuit of the heart into countless practices and the behavior to regulate its own belief. This is reflected in the norm of daily behavior, the norm of moral behavior and the norm of political behavior. In daily life, we should love life, struggle hard and pursue the highest spiritual realm. In moral behavior, we should be patriotic and honest, be friendly and dedicated, and pursue a harmonious and beautiful social state. The Marxism belief is essentially a kind of political belief, which requires the belief subject to take part in political activities actively, firmly support the Marxist political party-the authority and leadership of the Communist Party of China, to promote social progress and development.

\section{The Countermeasures for Education of Marxism Belief in College Students}

Education is an important way to cultivate Marxism belief in college students. General Secretary Xi Jinping emphasized at the National Conference on Ideological and political work in colleges and universities that the ideological and political work in colleges and universities is related to the fundamental issue on what kind of people to cultivate, how to cultivate people and who is cultivating people for (Lu \& Zhang, 2017). The university carries out the Marxism belief in 
education must insist using the morality to train people, starting from the four dimensions of the ideological and political education through the whole process of education, the realization of the whole process of education and all-round education.

\subsection{From Education Subject Dimension, Using the Dominance of University Teachers}

The first condition of education is that teachers must have belief in education, only if the teachers have strong belief in education, will spurt out the "love" and the education responsibility, will be willing to accept the cultivation and propagation of belief education and become initiative to increase knowledge and wisdom, will be devoted to selfless education to realize self-value, at the same time, construct students' ideal and educate the Marxism belief. This requires college ideological and political theory course teachers, counselors and all the teachers to enhance their own ideological and political quality, moral quality, physical and mental quality, ability quality and humanistic quality, regulate their behaviors and shoulder full educational responsibilities.

\subsection{From Education Object Dimension, Mobilizing the Initiative of College Students}

The theory of internal and external causes of dialectical materialism tells us that internal cause is the driving force of the development of things. College students are the educational objects of Marxism belief education in Colleges and universities. But in the process of accepting education, college students play the role of internal cause. Therefore, mobilizing the initiative of college students is the internal factors to carry out educational activities, which requires colleges and universities in the process of education to guide students to participate actively in the Marxism belief in education, mobilizing the subjective initiative of students, guide students to carry on self-education. We should strengthen the equal interaction between teachers and students and fully consider the psychological and cognitive characteristics of college students. To strengthen college students' social practice, through the visit and survey, "three steps to rural areas" and other social activities to make the students fully experience the change and development of China, let the students feel the Marxism theory and its chinalization guides China gain great achievements, let the students in practice generate the Marxism theory of cognition and identification, strengthen the belief in emotion and will.

\subsection{From Education Mediator Dimension, Exploring the Diversity of Educational Mediator}

The mediator of Marxism belief education in colleges and universities refers to the intermediary factor between the educational subjects and educational objects, which is a necessary condition for the intersection of educational subjects and educational objects. Among many mediator factors, the key point is to play 
the role of the ideological and political theory course as the main channel, the role of the main position and the role of the network new media of Marxism belief education for college students. Teaching the Marxism theory and Chinalization content through the class teaching system to college students, at the same time, we should pay attention to improving the teachers' professional ability on ideological and political theory, reforming teaching methods, improving teaching effect; make full use of the advantages of new media, play a good position of network educating advantages and network ideological and political education equality, and form a close combination of online and offline.

\subsection{From Education Environment Dimension, Developing the Appeal of Educational Atmosphere}

The role of environmental education cannot be underestimated. It is an important way to enhance the effectiveness of Marxism belief education by using the educational environment of colleges and universities. The important factor is the construction of campus culture. Marxism belief education in colleges and universities should be integrated into ideas of cultural confidence, give full play to the important role of literacy, cultural education. Putting the traditional Chinese culture, the cultural revolution, the socialist core values, and so on into the teaching concept, teaching characteristics, university spirit, make the teachers and students pursue common values and beliefs.

\section{Conclusion}

Faith is the spiritual pillar of everyone and even the Chinese nation. Research on education of Marxism belief of contemporary college students is a long-term and systematic process; it needs to actively expand the approaches of education, explore Marxism belief in the law of education, improve the effectiveness of education, achieve the unification between the scientific path of the socialist belief education with Chinese characteristics and realistic choice, and make the contemporary college students' Marxism belief education into effect.

\section{Fund Content}

The Nineteen Major Theoretical Subjects of the Party of Heilongjiang Bayi Agricultural University Research Findings in 2018, Project number sjd18208.

Research Achievements of Heilongiang Philosophy and Social Sciences Project, Project number 18ZXE716.

\section{Conflicts of Interest}

The author declares no conflicts of interest regarding the publication of this paper.

\section{References}

Chen, Y. Y., \& Wei, Y. L. (2016). The Dual Circumstances and Solutions of Marxist Belief 
Cultivation in College Students in the Age of Big Data. Studies on Mao Zedong Thought, 3, 139-143.

$\mathrm{Hu}$, S. Q. (2013). On the Urgency of Cultivating College Students' Marxist Beliefs. Research on Ideological and Political Education, 2, 43-46.

Huang, M. (2015). An Analysis of the Path of Contemporary College Students' Marxist Belief Education and Life. School Party Construction and Ideological Education, 8, 47-48.

Liu, J. R. (2013). The Spiritual Essence of Marxist Belief. Philosophy Research, 1, 20-23.

Liu, N. (2016). Research on the Cultivation Mechanism of Contemporary College Students' Marxist Belief. School Party Construction and Ideological Education, 20, 27-29.

Lu, Q. M., \& Zhang, J. W. (2017). On Strengthening the Education of College Students' Marxist View of History. Research on Ideological and Political Education, 1, 121-124.

Luo, C. Q. (2016). Ecological Thinking of Contemporary College Students' Marxist Belief Education. Theoretical Journal, 4, 13-16.

Qin, W. H. (2013). Reflections on Strengthening College Students' Marxist Belief Education. Studies in Ideological and Political Education, 8, 119-122.

Zhang, X. Q., \& Liu, X. H. (2014). Critical Belief: An Analysis of Marxist Ways of Belief. Exploration, 2, 166-170.

Zhang, X., \& Deng, S. H. (2015). On the Four Dimensions of Marxist Belief Education in Colleges and Universities. Studies on Mao Zedong Thought, 4, 152-155. 